\title{
Talent management and the HR function in cross-cultural mergers and acquisitions: the role and impact of bi-cultural identity
}

Article

Accepted Version

Liu, Y., Vrontis, D., Visser, M., Stokes, P., Smith, S., Moore, N., Thrassou, A. and Ashta, A. (2021) Talent management and the HR function in cross-cultural mergers and acquisitions: the role and impact of bi-cultural identity. Human Resource Management Review, 31 (3). 100744. ISSN 1053-4822 doi: https://doi.org/10.1016/j.hrmr.2020.100744 Available at https://centaur.reading.ac.uk/88540/

It is advisable to refer to the publisher's version if you intend to cite from the work. See Guidance on citing.

To link to this article DOI: http://dx.doi.org/10.1016/j.hrmr.2020.100744

Publisher: Elsevier

All outputs in CentAUR are protected by Intellectual Property Rights law, including copyright law. Copyright and IPR is retained by the creators or other copyright holders. Terms and conditions for use of this material are defined in the End User Agreement. 


\section{CentAUR}

Central Archive at the University of Reading

Reading's research outputs online 


\title{
Talent management and the HR function in cross-cultural mergers and acquisitions: the role and impact of bi-cultural identity
}

\begin{abstract}
This paper examines bi-cultural talent in relation to human resource management (HRM) practices in cross-cultural merger and acquisitions (M\&A). The intersection of HRM, bicultural talent management and cross-cultural M\&A literature proposes a conceptual framework to capture the complexity of bi-cultural talent management and reveals the dominant macro-characterization of the extant HRM literature focussing on a more microorientated perspective. The paper develops a matrix by underlining spatial dimensions (spanning micro-aspects of the individual employee through to the macro-entity of firm and its location in the macro-national cultural context) and temporal dimensions (consisting of pre-merger, during merger and post-merger phases). This provides a template which examines the multi-level dynamics of bi-cultural talent management. The argument identifies ways in which extant cross-cultural lenses require deeper understanding of bi-cultural talent management in M\&A settings. Future research directions and agendas are identified.
\end{abstract}

Key words: HRM, Talent Management, Bi-cultural individuals, Cross-Cultural, Mergers and Acquisitions

\section{Introduction}

Cross-cultural collaborations - whether strategic alliances, joint venture or mergers and acquisitions (M\&A) - can be a rewarding experience for organizations, however, equally, they can also constitute fraught and challenging undertakings (Angwin \& Vaara, 2005; Liu, Sarala, Xing, \& Cooper, 2017). As a mode of collaborative partnership, M\&As have been long employed by many organizations, ranging from small to multinational enterprises in the pursuit of a range of goals, including: rapid domestic and global growth and development (Bagdadli, Hayton, \& Perfido, 2014; Graebner, Eisenhardt, \& Roundy, 2010); corporate 'sharks' acquiring high-tech firms in order to access novel knowledge bases and to ignite innovation (Graebner \& Eisenhardt, 2004); emerging market firms venturing into advanced economies (Xing et al, 2017; Liu \& Vrontis, 2017); shared mental modes of teams in M\&A may facilitate innovation (Dao, et al. 2017), or, maturing born-global firms utilizing M\&A as a lever to survive or precipitate fast growth (Almor, Tarba, \& Margalit, 2014). Nevertheless, 
the consequences of collaborative partnerships for firm performance have been the topic of considerable debate, with many studies reporting high failure rates over a period of time (Cartwright \& Cooper, 1992; Weber, Tarba, \& Öberg, 2014; Graebner et al., 2016). Much of this work has taken place within what may be described as a 'macro-' frame of reference by which it is meant that the work has a tendency to focus on broad conceptualizations of 'organization', 'manager' and even 'individual' (Quah \& Young, 2005). Extant work casts these as 'units' for analysis, so to speak and perhaps offers less of a 'lived experience' - one perhaps dealing with the everyday felt realities of post-M\&A contexts (Knights \& Willmott, 1999). In counterpoint, there is a nascent literature examining identity and individuals from a more 'micro-' or lived experience and identity perceptive in post-M\&A settings (Terry, Carey \& Callan, 2001; Bartels et al, 2006; Björkman, Stahl \& Vaara, 2007; Xing \& Liu, 2016). While this literature on the M\&A domain has offered many valuable insights, the ability to predict success through M\&A remains poor. Even though M\&A has been acknowledged as having high failure rates, enthusiasm for this mode of business development remains high among a wide variety of organizations (Child, Faulkner, \& Pitkethly, 2001; Gomes et al, 2011). Nevertheless, it is increasingly argued that strategic fit between the partners is not enough and that success or failure of collaborative partnerships ultimately may depend on the individual and group-level responses to the change processes following the establishment and implementation of such partnerships (Larsson \& Finkelstein, 1999; Van Leeuwen, Van Knippenberg \& Ellemers, 2003; Khan et al., 2017). Consequently, HRM literature suggests that HRM insights and interventions can assist in ameliorating persistent questions and issues over variable success rates in the M\&A literature (Cartwright \& Cooper, 1993b; Weber \& Fried, 2011). In particular, the heightened consideration of human factors within M\&A may offer important developments with which to advance this literature stream (Seo \& Hill, 2005; Ellis, Reus \& Lamont, 2009; Liu et al., 2017; Sarala, Vaara, \& Junni, 2017). For example, the impact of M\&As on individuals and groups may differ widely depending on variegation of national and organizational cultural contexts (Vaara et al., 2012; Tarba et al., 2017); or HRM practices and sociocultural integration (Sarala et al, 2016; Aklamanu et al. 2016); and knowledge transfer and M\&A performance (Ahammad et al, 2016; Junni, et al. 2017). Therefore, it is against this backdrop that the current paper turns to considers aspects of talent management as a key element of human factors. Overall, talent management can be defined as: 
'activities and processes that involve the systematic identification of key positions that differentially contribute to the organization's sustainable competitive advantage, the development of a talent pool of high-potential and high-performing incumbents to fill these roles, and the development of a differentiated human resource architecture to facilitate filling these positions with competent incumbents, and to ensure their continued commitment to the organization' (Collings \& Mellahi, 2009: 304).

Moreover, scholars have suggested the need for a pluralistic approach in viewing talent management by taking account of contextual factors (Thunnissen, Boselie, \& Fruytier, 2013). For example, globalization and the mobility of talent affects individuals' career development and influences organizational practices, as witnessed, by way of illustration, by the highskilled talent expatriation and repatriation processes (Cerdin \& Brewster 2014; Baruch, Altman, \& Tung, 2016). The question of mobility also raises the issue of 'culture' - both in terms of the corporate cultures involved in the given M\&A and also the notion of companies and individuals emanating from particular national cultures which inform particular patterns of thinking and behaviors. These come with the attendant problematic challenge of representing, examining and differentiating the potential impact such generic cultural concepts (Hofstede, 1980, 1984, 1991; Trompenaars \& Hampden-Turner, 1993, 1997; Weber, Shenkar \& Raveh, 1996; Very et al, 1997; Morosini, Shane \& Singh, 1998; Drogendijk \& Slangen, 2006; Slangen, 2006; Stahl, \& Voigt, 2008; Sarala, 2010; Weber, Tarba \& Reichel, 2009, 2011). Furthermore and importantly, within M\&A situations where mergers occur between companies of varying national origin, a particular confluence of corporate cultures, national cultures, human factors and talent management emerges. Where mergers occur across national cultures, this creates an important space in M\&A for bi-cultural understandings. The role of bi-cultural individuals - those employees who are cognizant, fluent and effective in the dual-national cultural settings have the potential to bring processual insights and improvements to collaborative ventures (Teerikangas \& Very, 2006; Brock, 2005; Chakrabarti, Gupta-Mukherjee \& Jayaraman, 2009). As such, they represent an important yet relatively under-researched domain in relation to M\&A activities and, as individuals embody the site of a confluence and translation of both organizational and national cultures, they have the possibility of bringing their technical and cultural awareness to bear in a range of meaningful ways on HRM practices (Furusawa \& Brewster, 2015). Therefore, the present paper aims to fill this important gap guided by the following research question: 
How can talent management and the HR function leverage bi-cultural individuals to influence and mitigate the multi-level national cultural challenges in cross-cultural mergers and acquisitions from a process perspective?

In pursuance of this question, the paper is structured in the following manner: first, the argument considers the extant literature on HRM and talent management and, in particular, bi-cultural employees in cross-cultural M\&A. It identifies a number of prevalent conceptualizations within this work including, importantly, the influence of a recurrent macro and modernistic conceptual characterization. This is contextualized and challenged by, outlining and directing the argument towards a more individual and micro-orientated frame of reference. The overall macro-micro dynamic is positioned within a temporal and spatial matrix thus revealing further insights on the role and contribution of bi-cultural employees. In summary, the paper explores and discusses the issues that the model generates and recommends ways forward for the research domain summarizing the paper with a conclusion.

\section{Cross-Cultural M\&A and the role of the HR function}

HRM literature has underlined that the HR function constitutes a crucial component in the delivery of competitive advantage for organizations (Barney \& Wright, 1998; Lepak, Bartol, \& Erhardt, 2005; Marler, 2012; Sparrow, Cooper, \& Hird, 2014). By way of example, appropriate alignment between the HR function and the location of intellectual capital within an organization can facilitate the emergence of lean management thinking (Sparrow \& OtayeEbede, 2014). Moreover, as a means of securing competitive advantage, M\&A has become an increasingly integral feature of corporate life and one with which HR functions need to deal. Furthermore, M\&A involves substantial change for an organization, indeed, Bartunek \& Moch (1987) describe M\&A, as a third-order organizational change event (i.e. a major event requiring the ability of an entity or system to change schemata and structures in response to the demands of events which inherently necessitate active engagement of the management of employees before, during and after the merger (Schuler \& Jackson, 2001). As a consequence, the HR function finds itself center stage during M\&A, and especially so in the post-M\&A context where often differing cultures, both corporate, and national in the case of crosscultural mergers, have to be synthesised (Quah \& Young, 2005; Shook \& Roth, 2011). HR managers are thus positioned to play a strategic role in company-wide integration, post- 
merger processes and a support role for business unit transitions (Antila, 2006). Indeed, Björkman \& Søderberg, (2006) in their case study of financial corporation Nordea identified the HR function as playing a highly significant role in managing and integrating post-merger processes. Therefore, to summarize, the HR function finds itself situated in a position which overlooks the entire cultural terrain and spatial aspects of M\&A.

Moreover, timely action by the HR function is signaled as central to the success of any HR initiative in M\&A contexts (Schmidt, 2001; Weber \& Fried, 2011). It is suggested that the earlier the HR function gets involved in an M\&A deal, the greater the likelihood of successful integration of people and processes throughout the newly formed M\&A. This can also be linked to the importance of clarifying the overall strategic intent of the M\&A (Srinivasan \& Mishra, 2007; Rui \& Yip, 2008). When morale is high and people are engaged in developing and understanding joint visions and activities, individual and company performance have more likelihood of improvement (Cartwright \& Cooper, 1993a). Arguably, a major issue in M\&A failures might be caused where there is poorly defined intent and there is too little involvement of the HR function and organizational employees. This can lead to a minimum, or even no preparation (indeed, even the wrong preparation) in providing due diligence for employees along M\&A process (Gomes et al, 2013). Consequently, studies recommend the involvement of HR contingent upon the types of M\&A (Bagdadli et al., 2014; Napier, 1989; Schuler \& Jackson, 2001) and one key indicator affecting, for example, post-M\&A performance is employee retention (Ahammad et al., 2014; Weber \& Tarba, 2010). When organizations underestimate the elevated levels of employee disengagement that can occur during M\&A processes, it can produce uncertainty, emotional strain and loss of motivation and also take an enormous toll on employees which may, in turn, negatively affect a corporation's financial performance (Huy, 2002; Kavanagh \& Ashkanasy, 2006). Thus, HRM practices and HR functions operating at all spatial levels of organizational operation and at all chronological junctures of the merger are significant, however, as noted above, they are particularly important at supporting sensemaking (Weick, 1995; 2000) at the individual level in the post-M\&A context. For instance, rewards and fairness norms may influence employee emotional resilience during post-merger integration across national boundaries (Khan et al, 2017). Thus, the demonstrable need for: HR function involvement and the need to understand post-M\&A impacts and dynamics at detailed and granular levels turns the focus away from the predominant macro-focus on organizations and towards a more micro-level of analysis i.e. a focus on the individual, the local and the particular (Toulmin, 2003). This, is turn, means 
that the HR function needs a more intensely granular understanding of the talent among individuals operating in and around the organization in the M\&A context and the next stage of the argument turns to consider talent in greater detail.

Launched with the metaphorical statement of 'War for Talent' (Beechler \& Woodward, 2009), talent management offers a challenging phenomenon requiring both empirical refinement and theoretical advancement (Al Ariss, Cascio, \& Paauwe, 2014) in terms of, for instance: the global dimension and its implications for the actual HR management of talent (Tarique \& Schuler, 2010); HR functions needing to take account of the role of context and a pluralistic approach (Thunnissen, Boselie, \& Fruytier, 2013); a strategic perspective on talent management (Collings \& Mellahi, 2009); blended with, developing HR function awareness of myths and realities of global talent management (Minbaeva \& Collings, 2013). Talent management literature has expanded considerably in recent years together with a continued link to HR functions and HRM practices (Cappelli \& Keller, 2014). Nevertheless, a more nuanced understanding of the HR function in connection with talent may assist significantly in advancing the framing and articulation of specific aspects of the management of talent and especially in complex scenarios such as M\&A (Zhang et al 2015). For instance, the corporate HR function plays a significant role in managing the flow of talent through a large company by designing and implementing effective employee recruitment, retention and development strategies (Cappelli, 2008; Sparrow, Farndale, \& Scullion, 2013). A substantial literature has demonstrated M\&A's influence on employees and talent involved in the M\&A process. For example, research indicates that, after a poor M\&A experience, the first employees to leave are generally the ones who are talented (Bruner, 2009). Therein, this loss of talent can perhaps be attributed to the organizations involved in the given M\&A reacting too slowly in relocating key individuals in appropriate positions in the emergent structures. This has a consequent impact on the employees creating uncertainty, generating high anxiety, frustration, and low morale and eventually leading to reduced productivity (Seo \& Hill, 2005). Where M\&A occurs in cross-cultural (i.e. where companies from differing national contexts merge) situations these pressures may well be heightened due to the additional cultural issues and differences which have to be addressed (Sirmon \& Lane, 2004; Sarala, Vaara, \& Junni, 2017). Cross-cultural M\&A has the strong potential to evidence the presence and operation of biculturalism (where a person or group has equal knowledge, experience and practice of two different cultures) and this is a potentially important factor which has hitherto been under- 
researched in M\&A settings. The argument now progresses to introduce and consider how the HR function and HRM practices interact with bi-cultural individuals in M\&A settings.

\section{Bi-Cultural Employees in the Cross-Cultural M\&A Context - the Role of HRM}

The turn in M\&A research in recent decades from the macro-dimensions towards consideration of more micro-aspects, for example, individual identity and sensemaking (Weick, 1995; 2000) of human factors has been gradual but nevertheless notable (Vaara, Tienari \& Säntti, 2003; Tienari, 2005). In an increasingly globalised world the role of the bicultural (and indeed the multi-cultural) individual employee focuses on issues of how this particular talent is managed and engaged by the HR function in M\&A contexts. Bi-cultural employees are individuals who can identify with two (more) distinct cultures because they have internalized more than one cultural schema (Brannen \& Thomas, 2010). As noted above, a key caveat in relation to global talent mobility is the cross-cultural challenge and its implications for international HRM talent management (Collings, 2014) such as bi-cultural employees. Cultivating global competence with which to manage cross-cultural issues and leverage strategic opportunities is imperative for individuals who pursue global careers and for globalizing organizations to attain sustainable development (Cascio \& Boudreau, 2016). Moreover, bi-cultural employees may, as such, contribute to organizations by facilitating identity integration i.e. bringing about synthesis in post-M\&A settings (Fitzsimmons, 2013). One recent study elaborates the potential benefits brought by bi-cultural individuals to the M\&A domain by particular reference to domain-specific logic orientations (i.e. as opposed to knowledge-crossing boundaries) (Liu \& Isaak, 2016). Furthermore, a recent review of talent management suggests that a deeper appreciation of organizational contextual factors - wellexemplified by bi-cultural employees - may significantly assist the scholarly advancement of talent management research (Collings, Scullion, \& Vaiman, 2015). Therefore, with this in mind, we argue that bi-cultural individuals can play an important role, in multifarious ways, in cross-cultural M\&A activities (and especially the complexities of cultural fusion in postM\&A settings) by leveraging their bi-cultural competencies to the benefit of the M\&A. However, overall, the existing literature on M\&A has only begun to model and consider the mechanisms by which the bi-cultural individuals may contribute to the cross-cultural M\&A from a process perspective (Brannen \& Lee, 2014). Prior research shows that bi-cultural individuals bear certain characteristics, such as, for example, the ability to integrate ideas in 
more novel and creative ways, than perhaps is often available to other employees, by drawing from cultural resources (Leung \& Chiu, 2010). Furthermore, bi-culturalism is associated with higher flexibility (Chiu \& Hong, 2005), and bi-cultural individuals can develop increased cognitive complexity (Leung et al, 2008; Tadmor, Tetlock, \& Peng, 2009). However, equally, challenges in relation to re-acculturization oscillation (i.e. unpredictable switching between cultural modes, behaviors and affiliations) have also been identified as a potential issue for bi-cultural employees (Stokes et al, 2016).

Thus, bi-culturalism constitutes an important yet under-examined facet of organizational contexts and particularly M\&A contexts (Liu, 2017). However, equally, bi-culturalism is, by definition, founded on the notion of an individual being grounded in two national cultures and an examination of bi-cultural individuals therefore requires a means to consider the concept of national culture which, in itself, is underpinned with the earlier mentioned macromicro tensions in M\&A and organizations studies generally (Peng \& Luo, 2000; Bamberger, 2008). The notion of national culture (and by extension, the identity of bi-cultural individuals) has conventionally been examined through a number of well-known crosscultural frameworks, such as those produced by, for example: Hofstede (1980, 1984, 1991); Hofstede \& Bond (1988); Hofstede et al (1990); Trompenaars and Hampden-Turner (1993, 1997). These have been widely employed to make sense of cross-cultural (sic: companies from differing national contexts) and M\&A activity (Cardon 2008; Browaeys \& Price 2008). However, there have been a wide range of methodological and representational criticisms concerning Hofstede's framework including for example the oft-cited charge that it represents a range of national cultures based on the study of one company study (i.e. IBM). Thus, it would be unreasonable to claim that Hofstede's sample was readily representative of any notion of a given macro-national culture (or for the matter, a corporate culture within a national setting or the cultural characteristics of bi-cultural individuals) (McSweeney 2002). Notwithstanding these caveats, a recent content analysis of 24 years of publication in Journal of International Business Studies confirmed the dominant influence of Hofstede's cultural framework in cross-cultural studies (Stahl \& Tung, 2014). In specific relation to M\&A, a range of critiques have been developed on Hofstede's study and this body of work identifies a number of mediating factors, in connection with cultural aspects, which impact on performance. For example, Brock (2005) engages with Hofstede's work and underlines the importance of M\&A cultural match or mismatch processes as a successful integration mechanism and the scope for resource sharing and synergies. Furthermore, Chakrabarti, 
Gupta-Mukherjee \& Jayaraman (2009) signal that, while taking account of M\&A dealspecific variables and Hofstede-linked country-level effects, cultural differences and distance still impact on performance however, they note: 'cash [-based] and friendly acquisitions tend to perform better in the long run'. Nevertheless, given the longevity, extensive usage and the limitations identified in Hofstede's work, Kirkman, Lowe \& Gibson (2006) suggest that, although there has been wide use of Hofstede's framework, given its macro-limitations, there is scope to identify new ways of viewing and engaging with cultural dimensions especially in relation to a more individual or micro-level. In turn, the development of new and alternative approaches to understanding individual bi-cultural identity will facilitate a more granular appreciation of the role of such individuals in M\&A contexts and especially in post-M\&A situations.

Within M\&A commentary, alternative approaches have been brought to the debate on individual employee and organizational identity and in particular, a key theoretical premise employed within the work on identity includes Social Identity Theory (SIT) (Vaara, Tienari \& Säntti, 2003; Tienari, 2005; Vaara et al 2012). By extension, SIT also has potential explanatory power for the phenomenon of bi-culturalism within M\&A. SIT is intrinsically associated with the work of Tajfel (1974) and Turner (1987) and states that self-identity is a product of how a person perceives him or herself in relation to his or her predominant social group (Fraser \& Burchell 2001). Social identity occurs through the categorization of a person's identity as a consequence of interacting with others. A person makes sense of his or her identity by positioning him or herself in relation to others and identifying potential shared attributes. In turn, recognition of these shared attributes leads to the establishment of collective identities. This engenders the development of what can be termed 'primary groups' (those most important to the given individual and the shared identity under development) and, 'secondary groups' (those with weaker connectivity to the given individual/group) (Stolley 2005). Turner (1987) developed the work by extending it with in his studies on SelfCategorization which considered how people shape identity in relation to group ideals, stereotypes and self-concept. The act of refining one's actions to become an appropriate image of what is expected in a given context is the underlying principle of Turner's (1987) theory. The key notion therein is 'context' - the concern with self-perception as a personal identity to one in which social interaction plays a role in shaping identity (Haslam et al. 2000). 
Taking SIT and self-categorization as theoretical lenses, bi-cultural individuals are likely to possess multiple identities (Ramarajan, 2014) which may be dynamically constructed and developed over time. The varying degree of bi-cultural identity integration resonates with the variations in multi-cultural experience (Cheng et al , 2014). Furthermore, integrating various social identities at various levels of social identity theory can foster psychological bricolage (i.e. ad hoc pulling together of disparate elements to make a functional or operable process, entity or model) for the generation of creative solutions (Sanchez-Burks, Karlesky, \& Lee, 2015). Equally, and in a kindred manner, social constructivist perspectives have been employed to focus on the cultural dynamics of M\&A (Gertsen, Søderberg, \& Torp, 1998; Kleppestø, 2005). These perspectives view sociocultural integration as an identity-building process and broadly suggest that it is not cultural differences per se that create problems in the post-merger integration period but rather it is the way social and cultural boundaries are drawn and new organizational identities are developed. In these situations there is powerful scope for HRM involvement to facilitate socio-cultural integration (Xing \& Liu, 2016).

SIT has also been applied in broad cross-cultural contexts relating to talent management (Shaffer et al., 2012). In dealing with the complexities of cross-cultural M\&A, involving the fusing and blending of cultures, it can be seen that there is considerable scope for bi-cultural employees to play a significant intermediary and facilitating role between emergent and forming social groups in cross-cultural M\&A settings - and especially those groups more prone to being ensconced in traditional and more delineated identities. For instance, high skilled immigrants' success may well depend in large part on their motivation to integrate into their host country, where identity integration has an important bearing (Cerdin, Diné, \& Brewster, 2014). Moreover, from a cognitive perspective, it has been argued that multiculturalism can influence specific capabilities of multi-cultural managers in multinational companies (Lücke, Kostova, \& Roth, 2014). Nevertheless, some of this work has pointed at tensions between bi-cultural individuals and more 'mono-(national) cultural' employees. For instance, repatriate turnover can be explained by the perceived identity discrepancy between employees returning from international assignments and their non-international peers (Kraimer et al., 2012). Overall, while research on talent management has drawn on SIT (e.g. Bartels, Douwes, de Jong, \& Pruyn, 2006; Terry, Carey, \& Callan, 2001; van Leeuwen, van Knippenberg, \& Ellemers, 2003), the current discussion has progressed this to connect also with a more particular consideration of bi-cultural talent. By viewing, through the extension of social identity beyond extant analyses on talent management and macro-perceptions of 
cross-cultural M\&A, to consider bi-cultural employees as a special and significant group within M\&A cross-cultural situations this underscores value and potential understanding around this category of employees. Therefore, we argue that bi-cultural individuals can have strong potential to mitigate the challenges (and high failure rates) in cross-cultural M\&A through use of identity integration and multicultural experience.

In summary, as a third-order (i.e. major) change event (Bartunek \& Moch, 1987), M\&A can bring unexpected (beneficial or detrimental) consequences to existing routines and practices. Thus, it requires the proper structuring of organizations to facilitate task integration and people integration. In so doing, it calls for talent with the capable competencies and skills to serve the responsibility and to take up the position. Especially, when the all-too-common 'we' versus 'they' negative feeling prevails, talent retention becomes critical for knowledge transfer (Ahammad et al., 2016) and socio-cultural integration (Xing \& Liu, 2016). Furthermore, if the required skills cannot be found in the existing organizations, either acquirer or target, it needs to recruit the external (bi-cultural) talent to smooth the organizational change event. Talent may be hired temporally to work for the particular M\&A event, or recruited to join the organization as higher-level commitment. Previous research shows that HR practices may shift from external-oriented (hire temporal workers or consultants) to internal-oriented (recruit permanent employees), as the firm size increases and the organization becomes mature (Glaister et al., 2014). This means that organization needs to be flexible and agile to implement the HR practices in M\&A (Junni, Sarala, Tarba, \& Weber, 2015) and especially so when managing a highly perceptive bi-cultural talent pool. While dealing with cross-cultural M\&A, institutional difference becomes a salient factor influencing the M\&A process and outcome. Different institutions can have important bearings on $\mathrm{HR}$ practices in general and in collaborative partnership in particular. For instance, corporate governance in M\&A may be strongly influenced by the institution differences. US firms found it challenging to reorganize post-acquisition target organizations in Germany, largely due to the strong German labor union as compared to the US counterparts (Capron \& Guillén, 2009). In a similar vein, Chinese companies' unfamiliarity with the role of labor union in African countries introduced additional hurdles for the implementation of Chinese managers' HR practices in Africa (Xing et al., 2016). Hence, utilizing appropriate bi-cultural talent and leveraging the role of HR function can become critical to navigating more efficiently and effectively through the institutional differences in cross-cultural M\&A. The above discussion of bi-cultural talent in relation to SIT and self- 
categorization theories points the way towards a more micro and granular consideration of the role of specific bi-cultural talent domains in relation to cross-cultural M\&A. This counters and balances a more prevalent and dominant (macro-styled) account of cross-cultural M\&A which has relied extensively on particular models of culture. As an extension of the development of a more micro-orientated perspective it is also possible to build on,; extend the analysis, and consider identity more closely in relation to inter-connected time and place. This is to acknowledge the role of the confluence of time and place in shaping identity and, importantly, that as time and place transform so might individual identity. This is highly apposite and pertinent in the consideration of bi-cultural employees within cross-cultural M\&A events. Therefore, in the next and final phase of the development of a deeper understanding of bi-cultural individuals the argument develops and argues a multi-level approach by invoking the notions of 'spatial dimension' and 'temporal dimension' which can work to facilitate a nuanced understanding of bi-cultural talent management and HR function in cross-cultural M\&A. Thus, we posit the following proposition:

Proposition 1: The complexity of cross-cultural M\&A tends to be high, because it encounters issues and processes involving both the spatial dimension and the temporal dimension.

\section{Bi-Cultural talent management within cross-cultural M\&A: A spatial and temporal matrix}

The above discussion has considered the role of HR practices in relation to cross-cultural M\&A and, in particular, has introduced the role of bi-cultural talent management. Throughout the discussion, the dynamic and transforming nature and influence of bi-cultural employees has been highlighted. This influence can be deepened by framing and conceptualizing these dynamics in terms of time and place. Therein, it is possible to see 'place', operating at macro-levels such as notions of 'country' and 'national identity' (i.e. associated with a given geographical place); the 'organization' at a meso-level with its own corporate cultural atmosphere; and, at a more micro-level, individual employees (Angin \& Vaara, 2005; Teerikangas \& Very, 2006; Graebner et al., 2016) with their own talent and cultural, or here, bi-cultural identity in cross-cultural M\&A settings.

---Insert Figure 1 about here--- 
Thus, these various roles of 'place' in bi-cultural identity point at a series of inter-connecting spatial domains that can play a role in the M\&A domain. Furthermore, spatial dimensions can be seen as operating in relation to time dimensions whereby the national context and culture, together with the organization and the individual develop and evolve over time. In the case of a cross-cultural merger, this has conventionally been aligned with, and reflected in, following Schuler \& Jackson (2001) the descriptive phases of pre-merger, during the merger and postmerger (See Figure 2). Thus, there is a recognition that the merger takes place through these stages against dual (or indeed multiple) national contexts and organizational cultures (often reflecting national traits and issues). The bi-cultural employee thus also progresses, relates to, and evolves through a matrix of time and space/place in the various national, organizational and individual levels. Overall, this dynamic points at a temporal-spatial aspect and an opportunity to consider and understand how bi-cultural individuals may behave at each phase or in relation to each spatial dimension. As such, it creates the possibility of representing bicultural talent management in a multi-dimensional manner in cross-cultural M\&A contexts.

---Insert Figure 2 about here---

By situating bi-cultural employees within such a spatial and temporal cross-cultural M\&A matrix, and embracing a more process-orientated perspective on M\&A (Gomes et al., 2013; Liu \& Woywode, 2013), we build further granularity in the study of (bi-cultural) talent management. A number of studies have shown the variation of employee involvement and activities along the temporal M\&A process. For instance, pre-acquisition employee reactions from the acquired firm can significantly affect the dynamics of post-acquisition integration process (Teerikangas, 2012). Post-acquisition employees' willingness to cooperate largely influences the effectiveness of M\&A integration process (Melkonian, Monin \& Noorderhaven, 2011). However, in positing Schuler and Jackson's (2001) model it is important to underline the inherent and rigid linearity of trajectory it prescribes. In reality, many M\&A may seem to operate in a more staccato, or ebb and flow, manner rather than a 'clean' linear progression along or across such a matrix. Again, this raises a potentially important facilitation and smoothing role for bi-cultural employees (and perhaps particularly those at higher levels in the organization). Cross-cultural differences and differing perceptions in identity confluence between primary and secondary social groups may produce uncertainty and concerns during the, at times, chaos and confusion that M\&A can produce. Bi-cultural employees working with, and within HR functions, can assuage and allay 
concerns by operating as intermediaries who explain and account for differing understandings which may occur.

Therefore, we argue that the involvement of the HR department along the M\&A process needs to have an important bearing on, and interaction with, bi-cultural talent management and its resultant well-being and effectiveness. Consequently, the appropriate and in-depth planning of the possible value of bi-cultural talent management processes by $\mathrm{HR}$ in anticipation of the various chronological stages of an M\&A is clearly essential. This requires close liaison of HR functions in both organizations and working closely with these employees across the planned merger companies (in relation to their national settings). Once, the merger has taken place, researchers suggest that talent and outstanding employees at all levels within merged companies typically receive head hunter inquiries five days or less following the announcement of a merger but this is likely to be at a particular premium for bi-cultural individuals. Such events and factors are of vital importance because the failure to keep key people at the individual or micro-level of the organization after an M\&A can have a negative impact on overall macro-organizational performance (Zollo \& Meier, 2008). As such, the retention of key talented employees, and particularly bi-cultural employees, should be an explicitly planned objective of organizations in cross-cultural M\&A and the unplanned loss of such key employees jeopardizes the smooth transition and results in the loss of corporate intellectual capital (Gutknecht \& Keys, 1993). Equally, following a (cross-cultural) M\&A, there is high likelihood that the departure of talented bi-cultural key employees may ultimately lead the M\&A into a failure (kindred with postulations of Walsh, 1988; Weber, Rachman-Moore, \& Tarba, 2012). Thus, we posit the following:

Proposition 2: The retention of bi-cultural employees can positively influence the process and outcomes of cross-cultural M\&A, whereas the departure of bi-cultural employees can negatively affect the process and consequences of cross-cultural M\&A.

One of the additional major reasons for success in M\&As is 'due diligence' on both 'hard' (metrics, costs, budgeting, new organizational structure design) and 'soft' issues (culture, new M\&A organizational identity, power issues, resistance to change) within each of the above three stages. The retention of key and talented employees, such as bi-cultural individuals, is essential and represents a major and important 'soft' issue which will support the success of M\&A (Gomes et al, 2012). The uncertainty created by M\&A contributes to 
stress, and this leads to increased employee turnover (Marks \& Mirvis, 2001, 2011). Clearly, such anxieties can operate at the more organizational-group and department level, however, essentially they are rooted in the sense-making undertaken by the individual operating in micro-dimensions. Managing bi-cultural talent management across macro-micro/temporalspatial matrices and through the stages and time-span of cross-cultural M\&A can thus be seen as a complex task and a greater conceptual understanding can be of assistance. However, within the spatial-temporal consideration of bi-cultural HR talent management with a M\&A it should be underscored that not all M\&As are the same and that individual employee's attitudes at work following an acquisition may change depending on the types of acquisitions (Guerrero, 2008). The combination of the temporal dimensions with the spatial dimensions produces a more detailed representation with which to appreciate the challenges and perceptions outlined above.

---Insert Figure 3 about here---

In relation to the preceding argument we therefore posit the following:

Proposition 3a: HR function in concert with talent management practices may mitigate the cross-cultural M\&A challenges from a spatial perspective.

Proposition 3b: Identity integration and multicultural experience of bi-cultural employees may positively affect the cross-cultural M\&A process from a temporal perspective.

To summarize, we argue that to reduce the complexity of cross-cultural M\&A and increase the likelihood of cross-cultural M\&A success, the HR function and appropriate talent management can play a critical role. In particular, from a spatial perspective, the micro-level talent management practice, such as leveraging the advantages of bi-cultural employees may assist the organizations to address issues and challenges stemming from multiple levels. In so doing, it also leverages the power of micro-foundation and human side factors of M\&A (Sarala, Vaara, \& Junni, 2017; Liu et al., 2017). Furthermore, from a temporal perspective, the retention of bi-cultural employees and utilization of their competence may significantly facilitate the process of cross-cultural M\&A, especially the identity integration ability and 
multicultural experience of bi-cultural employees. Therefore, the appropriate alignment of HR function and talent management practices may contribute to a nuanced understanding, thus overcoming the obstacles and challenges of cross-cultural M\&A.

\section{Conclusion}

HR practices and their HRM practices face a wide range of challenges, and in a key, albeit under-researched, issue is the management of bi-cultural talent, in M\&A cross-collaboration contexts is a complex and multi-factored domain (Bagdadli, Hayton, \& Perfido, 2014; Graebner, Eisenhardt, \& Roundy, 2010). The extant literature has demonstrated a range of valuable models and insights into the issues that can arise more broadly into talent management and human factors in relation to M\&A. This paper builds on the extant body of research and identified and examined the under-researched area of bi-cultural individuals in cross-cultural M\&A. This allowed the argument to construct a model predicated on social identity and self-categorization theories (Tajfel, 1974; Turner, 1987). In addition, by extension it provided the possibility to generate a spatial-temporal representation of the bicultural individual within the dynamics of a cross-cultural M\&A process generating a contribution of a meta-analytical matrix which embodied dual national, micro-macro and spatial-temporal and dimensions. This supplied holistic models with which to analyze and comment on the development of the literature in the interconnected domains of HRM talent management and M\&A and also provided a framework for subsequent examination exploration in the field. In particular the paper points at a range of the detailed conceptual issues surrounding the temporal and spatial dimensions of bi-cultural talent management. In cross-cultural settings the temporal and spatial aspects have a more extensive range of factors for managers to consider (Fig 1). The argument elaborates and underlines the significance of bi-cultural employees in ensuring the potential success of cross-cultural. This means that this talent group merit particular attention from management and should be facilitated and guided towards supporting the key culturally integrative points of the merger. In equal measure, it is vital that bi-cultural employees are not overlooked or, worse, marginalised, by managerial actions and strategies during the cross-cultural M\&A. This could jeopardise the success of the M\&A and ultimately lead to its failure. These challenges can be dissected through spatial and temporal analyses. In terms of spatial dimensions there are a range of regional and national geographic considerations as well as organizational, divisional and functional spatial realms which need to be synergised. Moreover, the above dynamics play out across varying 
temporal, or time schedules and these can be seen as relative and perspective-driven depending on the individuals, bi-cultural and other, moving through differing spatial domains. The resultant complex matrix produces a challenging set of issues for managers to understand and address in an ongoing and evolutionary manner, however, the analysis, matrix-like consolidation and modeling of the issues provides a handrail which can assist managers to optimise the use of bi-cultural.

The discussion underlines that a more micro-appreciation of bi-cultural talent identity is necessary for HR functions to be able to optimize and engage such individuals. With crosscultural M\&A failure rates remaining persistently at a high level there is need to seek a more detailed set of lens and understandings so as to develop a micro- appreciation of the issues at play in this aspect of cross-cultural M\&A. With a deeper understanding of bi-cultural talent and the role it may play in creating more successful M\&A, HR functions can complement existing capacities and skills with which to successfully manage M\&A processes. Importantly, our conceptual framework combines the literature streams of HRM, Talent Management and M\&A from a dynamic and temporal-spatial multi-level perspective. The HR issues from lower level of analysis, such as bi-cultural individual and team, can affect the higher level of analysis, such as company, region, even country. For analytical purposes, we indicate the complexity and interconnected relationships in a more nuanced account of the possibility of multiple directions among these constitutive elements. We strongly argue that our conceptual endeavor can shed important light on future efforts to further advance our understanding of talent management and HR function in cross-border M\&A by taking our framework as a departure point. Moreover, this is underpinned and informed by a rich set of complementary literature which facilitates the meta-analytical exploration and explication of the micro and macro aspects of the spatial-temporal continuum. 


\section{References}

Aklamanu et al. (2016). The role of HRM and social capital configuration for knowledge sharing in post-M\&A integration: A framework for future empirical investigation. International Journal of Human Resource Management, 27(22), 2790-2822.

Ahammad, M. F., Tarba, S. Y., Liu, Y., \& Glaister, K. W. (2016). Knowledge transfer and cross-border acquisition performance: The impact of cultural distance and employee retention. International Business Review, 25(1), 66-75.

Al Ariss, A., Cascio, W. F., \& Paauwe, J. (2014). Talent management: Current theories and future research directions. Journal of World Business, 49(2), 173-179.

Almor, T., Tarba, S. Y., \& Margalit, A. (2014). Maturing, Technology-Based, Born-Global Companies: Surviving Through Mergers and Acquisitions. Management International Review, 54(4), 421-444.

Angwin, D., \& Vaara, E. (2005). Introduction to the special issue.'Connectivity' in merging organizations: Beyond traditional cultural perspectives. Organization Studies, 26(10), 14451453.

Antila, E. M. (2006). The role of HR managers in international mergers and acquisitions: a multiple case study. The International Journal of Human Resource Management, 17(6), 9991020.

Bagdadli, S., Hayton, J. C., \& Perfido, O. (2014). Reconsidering the Role of HR in M\&As: What Can Be Learned From Practice. Human Resource Management, 53(6), 1005-1025.

Bamberger, P. (2008). From the editors beyond contextualization: Using context theories to narrow the micro-macro gap in management research. Academy of Management Journal, 51(5), 839-846.

Barney, J. B., \& Wright, P. M. (1998). On becoming a strategic partner: The role of human resources in gaining competitive advantage. Human Resource Management, 37(1), 31-46.

Bartels, J., Douwes, R., Jong, M., \& Pruyn, A. (2006). Organizational identification during a merger: Determinants of employees' expected identification with the new organization. British Journal of Management, 17(S1), S49-S67.

Bartunek, J. M., \& Moch, M. K. (1987). First-order, second-order, and third-order change and organization development interventions: A cognitive approach. The Journal of Applied Behavioral Science, 23(4), 483-500.

Baruch, Y., Altman, Y., \& Tung, R. L. (2016). Career Mobility in a Global Era: Advances in Managing Expatriation and Repatriation. The Academy of Management Annals, 10(1), 841889.

Beechler, S., \& Woodward, I. C. (2009). The global "war for talent". Journal of International Management, 15(3), 273-285. 
Björkman, I., \& Søderberg, A.-M. (2006). The HR function in large-scale mergers and acquisitions: the case study of Nordea. Personnel Review, 35(6), 654-670.

Björkman, I., Stahl, G. K., \& Vaara, E. (2007). Cultural differences and capability transfer in cross-border acquisitions: The mediating roles of capability complementarity, absorptive capacity, and social integration. Journal of International Business Studies, 38(4), 658-672.

Blazejewski, S. (2012). Betwixt or beyond the lines of conflict? Biculturalism as situated identity in multinational corporations. Critical Perspectives on International Business, 8(2), 111-135.

Brannen, M. \& Lee, F. 2014. Bridging cultural divides: Traversing organizational and psychological perspectives on multiculturalism. In V. Benet-Martínez, \& Y.-y. Hong (Eds.), Oxford Handbook of Multicultural Identity: 417-437. New York, NY: Oxford University Press.

Brannen, M. Y. \& Thomas, D. C. (2010). Bicultural Individuals in Organizations Implications and Opportunity. International Journal of Cross Cultural Management, 10(1), 5-16.

Brock, D. M. (2005). Multinational acquisition integration: the role of national culture in creating synergies. International Business Review, 14(3), 269-288.

Bruner, R. F. (2009). Deals from hell: M\&A lessons that rise above the ashes. Hoboken, New Jersey: John Wiley \& Sons.

Cappelli P. (2008). Talent on Demand: Managing Talent in an Age of Uncertainty. Boston, Mass: Harvard Business Press.

Cappelli, P. \& Keller, J. (2014). Talent Management: conceptual approaches and practical challenges. Annual Review Organizational Psychology and Organizational Behavior, 1(1), 305-331.

Capron, L. \& Guillén, M. (2009). National corporate governance institutions and postacquisition target reorganization. Strategic Management Journal, 30(8), 803-833.

Cartwright, S. \& Cooper, C. L. (1992). Mergers and Acquisitions: The Human Factor: Butterworth-Heinemann Oxford.

Cartwright, S. \& Cooper, C. L. (1993a). The psychological impact of merger and acquisition on the individual: A study of building society managers. Human Relations, 46(3), 327-347.

Cartwright, S. \& Cooper, C. L. (1993b). The role of culture compatibility in successful organizational marriage. The Academy of Management Executive, 7(2), 57-70.

Cascio, W. F. \& Boudreau, J. W. (2016). The search for global competence: From international HR to talent management. Journal of World Business, 51(1), 103-114.

Chakrabarti, R., Gupta-Mukherjee, S. \& Jayaraman, N. (2009). Mars-Venus marriages: 
Culture and cross-border M\&A. Journal of International Business Studies, 40(2), 216-236.

Cerdin, J.-L. \& Brewster, C. (2014). Talent management and expatriation: Bridging two streams of research and practice. Journal of World Business, 49, 245-252.

Cerdin, J.-L., Diné, M. A. \& Brewster, C. (2014). Qualified immigrants'success: Exploring the motivation to migrate and to integrate. Journal of International Business Studies, 45(2), 151-168.

Cheng, C.-Y., Lee, F., Benet-Martínez, V. \& Huynh, Q.-L. (2014). Variations in Multicultural Experience: Influence of Bicultural Identity Integration on Socio-Cognitive Processes and Outcomes. In V. Benet-Martínez, \& Y.-y. Hong (Eds.), The Oxford handbook of multicultural identity: 276-299. New York, NY: Oxford University Press.

Child, J., Faulkner, D. \& Pitkethly, R. (2001). The Management of International Acquisitions: Oxford University Press.

Chiu, C.-Y. \& Hong, Y.-Y. (2005). Cultural competence: Dynamic processes. Handbook of Motivation and Competence: 489-505.

Collings, D. G. \& Mellahi, K. (2009). Strategic talent management: A review and research agenda. Human Resource Management Review, 19(4), 304-313.

Collings, D. G. (2014). Integrating global mobility and global talent management: Exploring the challenges and strategic opportunities. Journal of World Business, 49(2), 253-261.

Collings, D. G., Scullion, H. \& Vaiman, V. (2015). Talent management: Progress and prospects. Human Resource Management Review, 25(3), 233-235.

Dao, M. A., Strobl, A, Bauer, F. and Tarba, S. (2017). Triggering innovation through mergers and acquisitions: The role of shared mental models. Group \& Organization Management, 42(2), 195-236.

Drogendijk, R. \& Slangen, A. (2006). Hofstede, Schwartz, or managerial perceptions? The effects of different cultural distance measures on establishment mode choices by multinational enterprises. International Business Review, 15(4), 361-380.

Fitzsimmons, S. R. (2013). Multicultural employees: A framework for understanding how they contribute to organizations. Academy of Management Review, 38(4), 525-549.

Fraser, C. \& Burchell, B. (2001) Introducing Social Psychology. Oxford: Polity Press.

Furusawa, M. \& Brewster, C. (2015). The bi-cultural option for global talent management: The Japanese/Brazilian Nikkeijin example. Journal of World Business, 50, 133-143

Gertsen, M. C., Søderberg, A.-M. \& Torp, J. E. (1998). Cultural dimensions of international mergers and acquisitions: Walter de Gruyter.

Glaister, A. J., Liu, Y., Sahadev, S. \& Gomes, E. (2014). Externalizing, internalizing and fostering commitment: The case of born-global firms in emerging economies. Management 
International Review, 54(4), 473-496.

Gomes, E., Angwin, D., Peter, E. \& Mellahi, K. (2012). HRM issues and outcomes in African mergers and acquisitions: a study of the Nigerian banking sector. The International Journal of Human Resource Management, 23(14), 2874-2900.

Gomes, E., Angwin, D. N., Weber, Y. \& Tarba, S. Y. (2013). Critical Success Factors through the Mergers and Acquisitions Process: Revealing Pre- and Post-M\&A Connections for Improved Performance. Thunderbird International Business Review, 55(1), 13-35.

Gomes, E., Weber, Y., Brown, C. \& Tarba, S. Y. (2011). Mergers, Acquisitions, and Strategic Alliances: Understanding the Process. Basingstoke, UK: Palgrave Macmillan.

Graebner, M. E., \& Eisenhardt, K. M. (2004). The seller's side of the story: Acquisition as courtship and governance as syndicate in entrepreneurial firms. Administrative Science Quarterly, 49(3), 366-403.

Graebner, M. E., Eisenhardt, K. M. \& Roundy, P. T. (2010). Success and failure in technology acquisitions: Lessons for buyers and sellers. The Academy of Management Perspectives, 24(3), 73-92.

Graebner, M., Heimeriks, K., Huy, Q. \& Vaara, E. (2016). The process of post-merger integration: A review and agenda for future research. Academy of Management Annals, doi.org/10.5465/annals.2014.0078

Guerrero, S. (2008). Changes in employees' attitudes at work following an acquisition: a comparative study by acquisition type. Human Resource Management Journal, 18(3), 216236.

Gutknecht, J. E. \& Keys, J. B. (1993). Mergers, acquisitions and takeovers: Maintaining morale of survivors and protecting employees. The Academy of Management Executive, 7(3), 26-36.

Haslam, S.A., Powell, C, and Turner, J.C. (2000) Social Identity, Self-Categorization, and Work Motivation: Rethinking the Contribution of the Group to Positive and Sustainable Organisational Outcomes. Applied Psychology: An International Review, 49 (3), 319-339.

Hofstede, G. 1980. Culture's Consequences: International Differences in Work-Related Values. California: Sage Publications.

Hofstede, G. 1984. "The Cultural Relativity of the Quality of Life Concept." Academy of Management Review 9-(3), 389-398.

Hofstede, G. 1991. Cultures and Organizations: Software of the Mind. London: McGrawHill.

Hofstede, G. \& M. Bond. 1988. "The Confucius Connection; From Cultural Roots to Economic Growth.” Organizational Dynamics 16-(4), 5-23. 
Hofstede, G., B. Neuijen, D. Ohayv, G. and Sanders. 1990. "Measuring Organizational Cultures: A Qualitative and Quantitative Study across Twenty Cases." Administrative Science Quarterly 35(June): 286-316.

Hogg, M.A. (1996) Intergroup Processes, Group Structure and Social Identity. In Robinson, W.P. (ed) (1996). Social Groups and Identities. Developing the theory of Henri Tajfel. Butterworth Heinemann.

Huy, Q. N. (2002). Emotional balancing of organizational continuity and radical change: The contribution of middle managers. Administrative Science Quarterly, 47(1), 31-69.

Junni, P., Sarala, R. M., Tarba, S. Y. \& Weber, Y. (2015). The Role of Strategic Agility in Acquisitions. British Journal of Management, 26(4), 596-616.

Junni, P., Sarala, R. \& Tarba, S. (2017). The Role of Target Firm Power in M\&A Knowledge Transfer. International Studies of Management \& Organization, 48(1), 71-87.

Kavanagh, M. H. \& Ashkanasy, N. M. (2006). The impact of leadership and change management strategy on organizational culture and individual acceptance of change during a merger. British Journal of Management, 17(S1), S81-S103.

Khan, Z., Rao-Nicholson, R., Akhtar, P. \& He, S. (2017). Cross-border mergers and acquisitions of emerging economies' multinational enterprises-The mediating role of socialization integration mechanisms for successful integration. Human Resource Management Review. doi.org/10.1016/j.hrmr.2016.12.003

Khan, Z., Soundararajan, V., Wood, G. \& Ahammad, M. F. (2017). Employee emotional resilience during post-merger integration across national boundaries: Rewards and the mediating role of fairness norms. Journal of World Business doi.org/10.1016/j.jwb.2017.06.009

Kleppest $\varnothing$, S. (2005). The construction of social identities in mergers and acquisitions. In G. Stahl, \& M. Mendenhall (Eds.), Mergers and Acquisitions: Managing Culture and Human Resources: 130-151.

Knights, D. and Willmott, H. (1999) Management Lives: Power and Identity in Work Organizations, London, Sage Publications.

Kraimer, M. L., Shaffer, M. A., Harrison, D. A. \& Ren, H. (2012). No place like home? An identity strain perspective on repatriate turnover. Academy of Management Journal, 55(2), 399-420.

Larsson, R. \& Finkelstein, S. (1999). Integrating strategic, organizational, and human resource perspectives on mergers and acquisitions: A case survey of synergy realization. Organization Science, 10(1), 1-26.

Larsson, R. \& Risberg, A. (1998). Cultural awareness and national versus corporate barriers to acculturation. in M. Cardel Gertsen, A.-M. Soderberg, \& J. E. Torp (Eds.), Cultural 
Dimensions of International Mergers and Acquisitions (pp. 39-55). Berlin: Walter de Gruyter $\mathrm{GmbH}$.

Lepak, D. P., Bartol, K. M. \& Erhardt, N. L. (2005). A contingency framework for the delivery of HR practices. Human Resource Management Review, 15(2), 139-159.

Leung, A. K. \& Chiu, C.. (2010). Multicultural Experience, Idea Receptiveness, and Creativity. Journal of Cross-Cultural Psychology, 41(5-6), 723-741.

Leung, A. K., Maddux, W. W., Galinsky, A. D., \& Chiu, C. 2008. Multicultural experience enhances creativity: the when and how. American Psychologist, 63(3), 169-181.

Liu, X., Gao, L., Lu, J. \& Wei, Y. (2015). The role of highly skilled migrants in the process of inter-firm knowledge transfer across borders. Journal of World Business, 50(1), 56-68.

Liu, Y. (2017). Born global firms' growth and collaborative entry mode: the role of transnational entrepreneurs. International Marketing Review, 34(1), 46-67.

Liu, Y. \& Woywode, M. (2013). Light-touch Integration of Chinese Cross-Border M\&A: The Influences of Culture and Absorptive Capacity, Thunderbird International Business Review, 55(4), 469-483.

Liu, Y. \& Vrontis, D. (2017). Emerging markets firms venturing into advanced economies: The role of context. Thunderbird International Business Review, 59(3), 255-261.

Liu, Y., Sarala, R.M., Cooper, C. \& Xing, Y. (2017). Human side of collaborative partnerships: A micro-foundational perspective. Group \& Organization Management, $42(2), 151-162$.

Liu, Y. \& Isaak, A. (2016). Effectuation spectra in chinese high-tech entrepreneurship: Domain specific logic orientations and cross-border M\&A. In S. Y. Tarba, \& Y. Weber (Eds.), Mergers and Acquisitions, Entrepreneurship and Innovation: 111-148: Emerald Group Publishing Limited.

Lücke, G., Kostova, T. \& Roth, K. (2014). Multiculturalism from a cognitive perspective: Patterns and implications. Journal of International Business Studies, 45(2), 169-190.

Marks, M. L. \& Mirvis, P. H. (2001). Making mergers and acquisitions work: Strategic and psychological preparation. The Academy of Management Executive, 15(2), 80-92.

Marks, M. L. \& Mirvis, P. H. (2011). A framework for the human resources role in managing culture in mergers and acquisitions. Human Resource Management, 50(6), 859-877.

Marler, J. H. (2012). Strategic human resource management in context: A historical and global perspective. The Academy of Management Perspectives, 26(2), 6-11.

Melkonian, T., Monin, P. \& Noorderhaven, N. G. (2011). Distributive justice, procedural justice, exemplarity, and employees' willingness to cooperate in M\&A integration processes: An analysis of the Air France-KLM merger. Human Resource Management, 50(6), 809-837. 
Minbaeva, D. \& Collings, D. G. (2013). Seven myths of global talent management. The International Journal of Human Resource Management, 24(9), 1762-1776.

Morosini, P., Shane, S. \& Singh, H. (1998). National cultural distance and cross-border acquisition performance. Journal of International Business Studies, 29(1), 137-158.

Napier, N. K. (1989). Mergers and acquisitions, human resource issues and outcomes: A review and suggested typology*. Journal of Management Studies, 26(3), 271-290.

Peng, M. W. \& Luo, Y. (2000). Managerial ties and firm performance in a transition economy: The nature of a micro-macro link. Academy of Management Journal, 43(3), 486501.

Quah, P. \& Young, S. (2005). Post-acquisition Management:: A Phases Approach for Crossborder M\&As. European Management Journal, 23(1), 65-75.

Ramarajan, L. (2014). Past, present and future research on multiple identities: Toward an intrapersonal network approach. The Academy of Management Annals, 8(1), 589-659.

Rui, H. \& Yip, G. S. (2008). Foreign acquisitions by Chinese firms: A strategic intent perspective. Journal of World Business, 43(2), 213-226.

Sanchez-Burks, J., Karlesky, M. J. \& Lee, F. (2015). Psychological Bricolage: Integrating Social Identities to Produce Creative Solutions. In C. E. Shalley, M. A. Hitt, \& J. Zhou (Eds.), The Oxford Handbook of Creativity, Innovation, and Entrepreneurship: 93-102. New York, NY: Oxford University Press.

Sarala, R. M. (2010). The impact of cultural differences and acculturation factors on postacquisition conflict. Scandinavian Journal of Management, 26(1), 38-56.

Sarala, R. M., Junni, P., Cooper, C. L. \& Tarba, S. Y. (2014). A Sociocultural Perspective on Knowledge Transfer in Mergers and Acquisitions. Journal of Management, Published online before print April 16, 2014.

Sarala, R. M., Vaara, E. \& Junni, P. (2017). Beyond merger syndrome and cultural differences: New avenues for research on the "human side" of global mergers and acquisitions (M\&As). Journal of World Business. doi.org/10.1016/j.jwb.2017.10.001

Schmidt, J. A. (2001). The correct spelling of M\&A begins with HR. HR Magazine, 6, 102108.

Schuler, R. \& Jackson, S. (2001). HR issues and activities in mergers and acquisitions. European Management Journal, 19(3), 239-253.

Seo, M.-G. \& Hill, N. S. (2005). Understanding the Human Side of Merger and Acquisition An Integrative Framework. The Journal of Applied Behavioral Science, 41(4), 422-443.

Shaffer, M. A., Kraimer, M. L., Chen, Y.-P. \& Bolino, M. C. (2012). Choices, challenges, and career consequences of global work experiences a review and future agenda. Journal of Management, 38(4), 1282-1327. 
Shook, L. \& Roth, G. (2011). Downsizings, mergers, and acquisitions: Perspectives of human resource development practitioners. Journal of European Industrial Training, 35(2), 135-153.

Sirmon, D. G. \& Lane, P. J. (2004). A model of cultural differences and international alliance performance. Journal of International Business Studies, 35(4), 306-319.

Slangen, A. H. (2006). National cultural distance and initial foreign acquisition performance: The moderating effect of integration. Journal of World Business, 41(2), 161-170.

Sparrow, P., Cooper, C. \& Hird, M. (2014). Do we need HR? Repositioning people management for success. Basingstoke, Hampshire, UK: Palgrave Macmillan.

Sparrow, P., Farndale, E. \& Scullion, H. (2013). An empirical study of the role of the corporate HR function in global talent management in professional and financial service firms in the global financial crisis. The International Journal of Human Resource Management, 24(9), 1777-1798.

Sparrow, P. \& Otaye-Ebede, L. (2014). Lean management and HR function capability: the role of HR architecture and the location of intellectual capital. The International Journal of Human Resource Management, 25(21), 2892-2910.

Srinivasan, R. \& Mishra, B. P. (2007). Why do firms merge/acquire: an analysis of strategic intent in recent M\&A activity among Indian firms. IIMB Management Review, 19(4), 388402.

Stahl, G. K. \& Tung, R. L. (2014). Towards a more balanced treatment of culture in international business studies: The need for positive cross-cultural scholarship. Journal of International Business Studies, 46(4), 391-414.

Stahl, G. K. \& Voigt, A. (2008). Do cultural differences matter in mergers and acquisitions? A tentative model and examination. Organization Science, 19(1), 160-176.

Stokes, P., Liu, Y., Smith, S., Leidner, S., Moore, N. \& Rowland, C. (2016). Managing talent across advanced and emerging economies: HR issues and challenges in a Sino-German strategic collaboration. The International Journal of Human Resource Management, 27(20), 2310-2338.

Stolley, K.S. (2005) The Basics of Sociology. Greenwood Publishing

Tadmor, C. T., Tetlock, P. E. \& Peng, K. (2009). Acculturation strategies and integrative complexity the cognitive implications of biculturalism. Journal of Cross-Cultural Psychology, 40(1), 105-139.

Tajfel, H. (1974). Social identity and intergroup behavior. Information (International Social Science Council), 13(2), 65-93.

Tarba, S. Y., Ahammad, M. F., Junni, P., Stokes, P. \& Morag, O. (2017). The Impact of Organizational Culture Differences, Synergy Potential, and Autonomy Granted to the 
Acquired High-Tech Firms on the M\&A Performance. Group \& Organization Management, 1059601117703267.

Tarique, I. \& Schuler, R. S. (2010). Global talent management: Literature review, integrative framework, and suggestions for further research. Journal of World Business, 45(2), 122-133. Teerikangas, S. \& Very, P. (2006). The culture-performance relationship in M\&A: From yes/no to how. British Journal of Management, 17(S1), S31-S48.

Teerikangas, S. (2012). Dynamics of acquired firm pre-acquisition employee reactions. Journal of Management, 38(2), 599-639.

Terry, D. J., Carey, C. J. \& Callan, V. J. (2001). Employee adjustment to an organizational merger: An intergroup perspective. Personality and Social Psychology Bulletin, 27(3), 267280.

Tienari, J., Søderberg, A. M., Holgersson, C. \& Vaara, E. (2005). Gender and National Identity Constructions in the Cross - Border Merger Context. Gender, Work \& Organization, 12(3), 217-241.

Thunnissen, M., Boselie, P. \& Fruytier, B. (2013). Talent management and the relevance of context: Towards a pluralistic approach. Human Resource Management Review, 23(4), 326336.

Toulmin, S. (2003) Return to Reason, Boston, Harvard University Press.

Trompenaars, F. \& C. Hampden-Turner. 1993. The Seven Cultures of Capitalism: Value Systems for Creating Wealth in the United States, Britain, Japan, Germany, France, Sweden and the Netherland. London (UK): Piatkus.

Trompenaars, F. and C. Hampden-Turner. 1997. Riding the Waves of Culture: Understanding Cultural Diversity in Business. London (UK) Nicholas Brearley.

Turner, J.C., (1987) Rediscovering The Social Group. A Self-Categorization Theory. Oxford; Blackwell.

Ulrich, D. (1998). A new mandate for human resources. Harvard Business Review, 76, 124135 .

Vaara, E. (2002). On the discursive construction of success/failure in narratives of postmerger integration. Organization Studies, 23(2), 211-248.

Vaara, E. (2003). Post-acquisition Integration as Sensemaking: Glimpses of Ambiguity, Confusion, Hypocrisy, and Politicization. Journal of Management Studies, 40(4), 859-894.

Vaara, E., Tienari, J. \& Säntti, R. (2003). The international match: Metaphors as vehicles of social identity-building in cross-border mergers. Human Relations, 56(4), 419-451. 
Vaara, E., Sarala, R., Stahl, G. K. \& Björkman, I. (2012). The impact of organizational and national cultural differences on social conflict and knowledge transfer in international acquisitions. Journal of Management Studies, 49(1), 1-27.

Van Leeuwen, E., van Knippenberg, D. \& Ellemers, N. (2003). Continuing and changing group identities: The effects of merging on social identification and ingroup bias. Personality and Social Psychology Bulletin, 29(6), 679-690.

Very, P., Lubatkin, M., Calori, R. \& Veiga, J. (1997). Relative standing and the performance of recently acquired European firms. Strategic Management Journal, 593-614.

Walsh, J. P. (1988). Top management turnover following mergers and acquisitions. Strategic Management Journal, 9(2), 173-183.

Weber, Y., Shenkar, O. \& Raveh, A. (1996). National and corporate cultural fit in mergers/acquisitions: An exploratory study. Management Science, 42(8), 1215-1227.

Weber, Y. \& Fried, Y. (2011). Guest editors' note: The dynamic of employees' reactions during postmerger integration process. Human Resource Management, 50(6), 777-781.

Weber, Y., Rachman-Moore, D. \& Tarba, S. Y. (2012). HR practices during post-merger conflict and merger performance. International Journal of Cross Cultural Management, 12(1), 73-99.

Weber, Y. \& Tarba, S. Y. (2010). Human resource practices and performance of mergers and acquisitions in Israel. Human Resource Management Review, 20(3), 203-211.

Weber, Y., Tarba, S. Y. \& Öberg, C. (2014). A Comprehensive Guide to Mergers and Acquisitions Management: Managing the Critical Success Factors Across Every Stage of the M\&A Process. New Jersey, USA: Pearson \& Financial Times Press.

Weber, Y., Tarba, S. \& Reichel, A. (2009). International mergers and acquisitions performance revisited-the role of cultural distance and post. In Advances in Mergers and Acquisitions (pp. 1-17). Bingley, Emerald Group Publishing Limited.

Weber, Y., Tarba, S. Y. \& Reichel, A. (2011). A model of the influence of culture on integration approaches and international mergers and acquisitions performance. International Studies of Management \& Organization, 41(3), 9-24.

Weick, K. (1995) Sensemaking in Organizations, London, Sage Publications.

Weick, K. (2000) Making Sense of the Organization, London, Wiley-Blackwell.

Xing, Y. \& Liu, Y. (2016). Linking leaders' identity work and human resource management involvement: the case of sociocultural integration in Chinese mergers and acquisitions. The International Journal of Human Resource Management, 27(20), 2550-2577.

Xing, Y., Liu, Y., Tarba, S. Y. \& Cooper, C. L. (2016). Intercultural influences on managing African employees of Chinese firms in Africa: Chinese managers' HRM practices. 
International Business Review, 25(1), 28-41.

Xing, Y., Liu, Y., Tarba, S. Y. \& Cooper, C. (2016). Servitization in mergers and acquisitions: Manufacturing firms venturing from emerging markets into advanced economies, International Journal of Production Economics, DOI 10.1016/j.ijpe.2016.12.010.

Zhang, J., Ahammad, M. F., Tarba, S., Cooper, C. L., Glaister, K. W. \& Wang, J. (2015). The effect of leadership style on talent retention during merger and acquisition integration: Evidence from China. The International Journal of Human Resource Management, 26, 10211050 .

Zollo, M. \& Meier, D. (2008). What is M\&A performance? The Academy of Management Perspectives, 22(3), 55-77. 
Figure 1. Temporal and Spatial Matrix of Bi-Cultural Individual Dynamics in Cross-Cultural M\&A Contexts

\begin{tabular}{|c|c|c|c|c|}
\hline DIMENSIONS & Temporal $\rightarrow$ & Pre-Merger & During Merger & Post-Merger \\
\hline \multicolumn{5}{|l|}{ Spatial $\downarrow$} \\
\hline Country Culture & & $\begin{array}{l}\text { Bi-cultural employee provides } \\
\text { HR function with early } \\
\text { diagnostics and insights into } \\
\text { national culture for the cross- } \\
\text { cultural M\&A }\end{array}$ & $\begin{array}{l}\text { Bi-cultural employees work } \\
\text { with HR function to } \\
\text { indicate critical incidents } \\
\text { and national culturally } \\
\text { significant moments for the } \\
\text { M\&A development }\end{array}$ & $\begin{array}{l}\text { Bi-cultural employees work } \\
\text { with HR function to translate } \\
\text { ongoing national cultural } \\
\text { context into the organizational } \\
\text { fabric }\end{array}$ \\
\hline $\begin{array}{l}\text { Organizational } \\
\text { Culture }\end{array}$ & & $\begin{array}{l}\text { HR function aims to prepare } \\
\text { the M\&A synergized cross- } \\
\text { cultural organizational culture } \\
\text { by identifying and consulting } \\
\text { with bi-cultural employees and } \\
\text { advisors }\end{array}$ & $\begin{array}{l}\text { HR function works to build } \\
\text { cross-cultural liaison for the } \\
\text { ongoing M\&A by } \\
\text { assembling bi-cultural } \\
\text { individuals into relevant } \\
\text { teams and groupings }\end{array}$ & $\begin{array}{l}\text { HR function works to ensure } \\
\text { that the newly combined and } \\
\text { emergent cross-cultural } \\
\text { environment is functioning } \\
\text { appropriately. HR function } \\
\text { works to ensure bi-cultural } \\
\text { staff are retained as they have } \\
\text { ready currency in the } \\
\text { international job market }\end{array}$ \\
\hline $\begin{array}{l}\text { Individual } \\
\text { Identity }\end{array}$ & & $\begin{array}{l}\text { Bi-cultural individuals find } \\
\text { that the cultural dimensions of } \\
\text { their identity are given in a } \\
\text { premium in advance of the } \\
\text { cross-cultural merger }\end{array}$ & $\begin{array}{l}\text { Bi-cultural individuals may } \\
\text { feel that the new cross- } \\
\text { cultural collaborative } \\
\text { environment operates well } \\
\text { for them. As such they } \\
\text { work in tandem with the } \\
\text { HR function to engender } \\
\text { the smooth running of the } \\
\text { operation. Alternatively } \\
\text { they may experience } \\
\text { accultural oscillations }\end{array}$ & $\begin{array}{l}\text { Bi-cultural individuals } \\
\text { continue to support and } \\
\text { develop the emergent and } \\
\text { evolving cross-cultural } \\
\text { environment in conjunction } \\
\text { with the HR function. } \\
\text { Disaffected and dissatisfied bi- } \\
\text { cultural employees may leave } \\
\text { the organization. }\end{array}$ \\
\hline
\end{tabular}


Figure 2. A multi-level spatial conceptual framework on talent management and HR function in cross-cultural M\&A

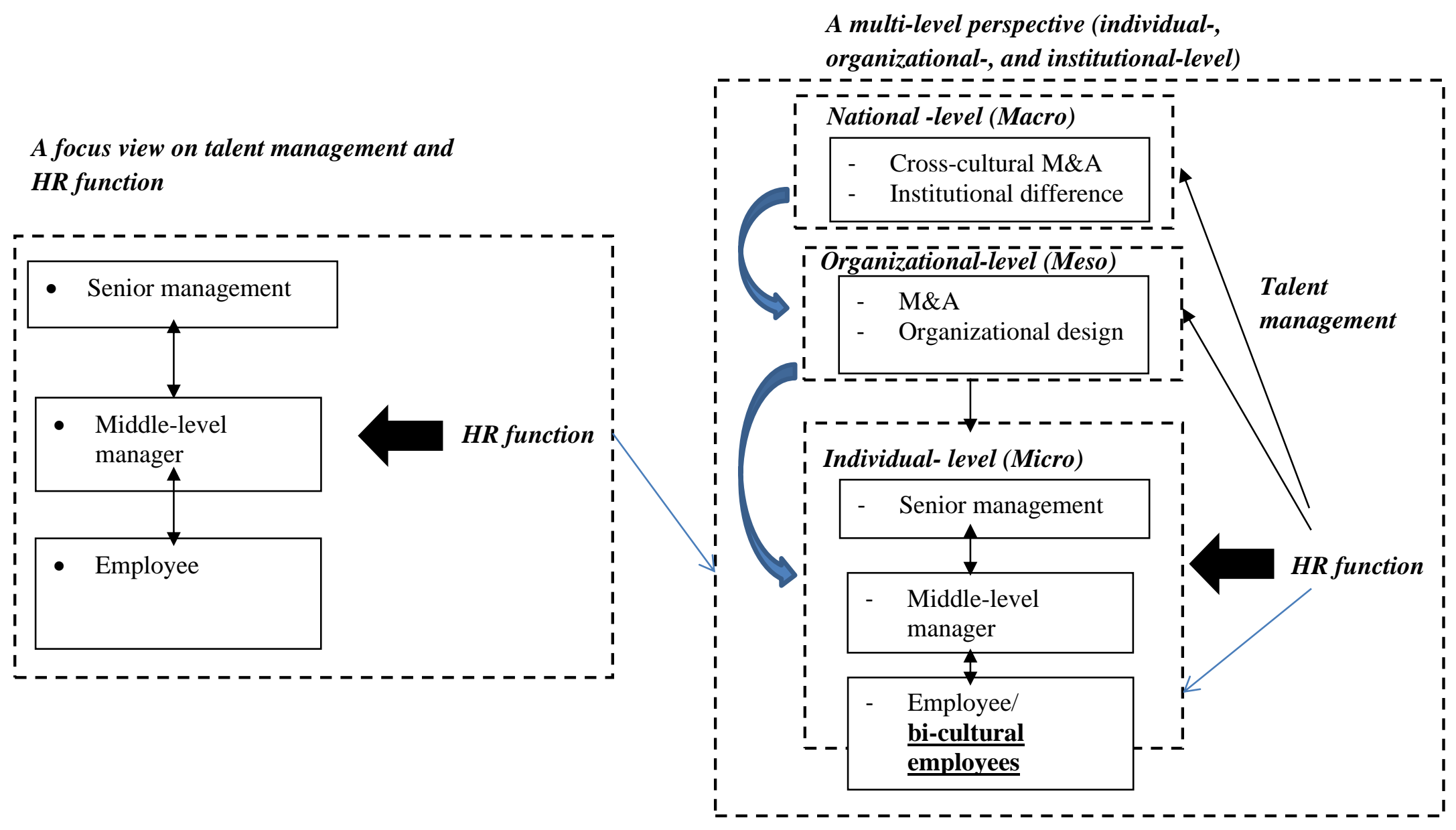


Figure 3. A conceptual framework on influence of bi-cultural individuals along cross-cultural M\&A temporal process

\section{Pre- $M \& A$}

\section{Searching and planning}

During- $M \& A$

Integration

\section{$\longrightarrow$ Post-M\&A}

\section{Solidification and Assessment}

- Solidifying leadership and staffing,

- Assessing the new strategies and structures,

- Assessing the new structure,

- Assessing the new HR,

- Assessing the concerns of stakeholders,

- Revising as needed,

- Learning from the process.
- Systematic and extensive pre-selection and selection

- Staff due diligence employees,

- Managing the change process,

- Communicating to and invoicing stakeholders,

- Deciding the HR policies and practices.

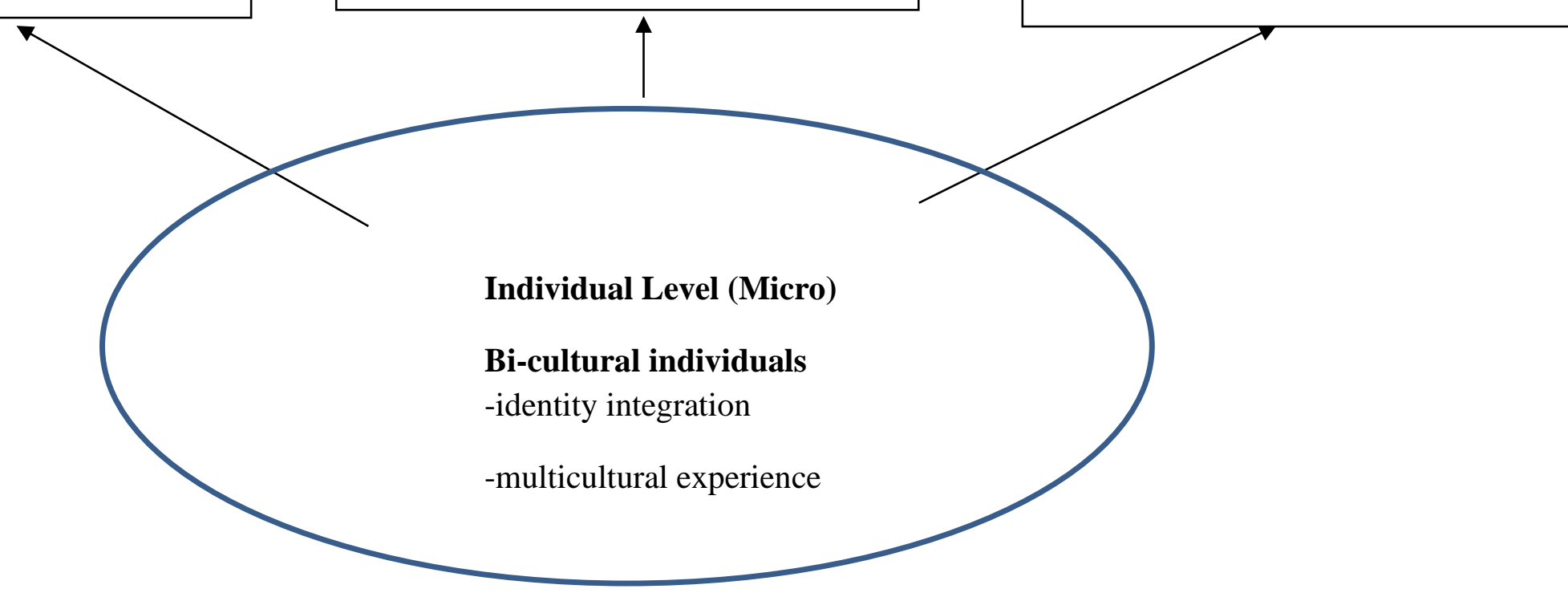

